\title{
Characterization of extracellular polymers synthesized by tropical intertidal biofilm bacteria
}

\author{
B.O. Ortega-Morales ${ }^{1^{\star}}$, J.L. Santiago-García ${ }^{1}$, M.J. Chan-Bacab ${ }^{1}$, X. Moppert $^{2}$, E. \\ Miranda-Tello ${ }^{3}$, M.L. Fardeau ${ }^{3}$, J.C. Carrero ${ }^{4}$, P. Bartolo-Pérez ${ }^{1,5}$, Alex Valadéz-González ${ }^{6}$ \\ and J. Guezennec ${ }^{2}$ \\ ${ }^{1}$ Departamento de Microbiología Ambiental y Biotecnología, Programa de Corrosión del Golfo \\ de México, Universidad Autónoma de Campeche. Av. Agustín Melgar s/n, Col. Buenavista, C.P. \\ 24030, Campeche, México. \\ ${ }^{2}$ IFREMER, Plouzané, 29210, France. \\ ${ }^{3}$ Institute de Recherche pour le Développement UR-101, Extrêmophiles, IFR-BAIM, Universités de \\ Provence et de la Méditerranée, ESIL case 925, 163 avenue de Luminy, 13288 Marseille, Cedex 09, \\ France. \\ ${ }^{4}$ Department of Immunology, Instituto de Investigaciones Biomédicas, Universidad Nacional \\ Autónoma de México, 04510 México, D.F. \\ ${ }^{5}$ CINVESTAV-IPN Mérida, Departamento de Física-Aplicada, Yucatán, México, \\ ${ }^{6}$ Departamento de Materiales, Centro de Investigación \\ Científica de Yucatán, A.C. Calle 43 No. 130 Col. Chuburná de Hidalgo. CP 97200, Mérida, \\ Yucatán, México. \\ *: Corresponding author : B.O. Ortega-Morales, Departamento de Microbiología Ambiental y Biotecnología, \\ Programa de Corrosión del Golfo de México, Universidad Autónoma de Campeche Av., Agustín Melgar s/n, Col. \\ Buenavista, C.P. 24030, Campeche, México. E-mail: beortega@uacam.mx
}

\begin{abstract}
:
This study was performed to determine the potential of tropical intertidal biofilm bacteria as a source of novel exopolymers (EPS).

Methods and Results: A screening procedure was implemented to detect EPS-producing biofilm bacteria. Isolates MC3B-10 and MC6B-22, identified respectively as a Microbacterium species and Bacillus species by $16 \mathrm{~S}$ rDNA and cellular fatty acids analyses, produced different EPS, as evidenced by colorimetric and gas chromatographic analyses. The polymer produced by isolate MC3B-10 displays significant surfactant activity, and may chelate calcium as evidenced by spectroscopic analysis.
\end{abstract}

Conclusions: Polymer MC3B-10 appears to be a glycoprotein, while EPS MC6B-22 seems to be a true polysaccharide dominated by neutral sugars but with significant concentrations of uronic acids and hexosamines. EPS MC3B-10 possesses a higher surfactant activity than that of commercial surfactants, and given its anionic nature, may chelate cations thus proving useful in bioremediation. The chemical composition of polymer MC6B-22 suggests its potential biomedical application in tissue regeneration.

Significance and Impact of the Study: This is the first report of a Microbacterium species producing EPS with surfactant properties, which expands our knowledge of the micro-organisms capable of producing these biomolecules. Furthermore, this work shows that tropical intertidal environments are a nonpreviously recognized habitat for bioprospecting EPS-producing bacteria, and that these molecules might be involved in ecological roles protecting the cells against dessication. 


\section{INTRODUCTION}

72 Bacteria live predominantly associated with surfaces as biofilm communities in natural and man-

73 made environments in both terrestrial and aquatic settings (Costerton et al. 1981; Guezennec et

74 al. 1998; Stoodley et al. 2002). This life style has often been interpreted as an ecological strategy

75 to cope with physical and chemical stress. Marine biofilms have been shown to play key

76 ecological roles sustaining populations of sessile invertebrate grazers (Thompson et al. 2000) and

77 cycling carbon and nitrogen (Magalhães et al. 2003).

79 Recently, marine biofilms have also attracted attention due to their biotechnological potential.

80 Vincent et al. (1994) and Raguenes et al. (1996) assessed the potential of biofilm-derived

81 bacteria from deep-sea hydrothermal vents as producers of new exopolysaccharides, some with

82 potential application in the food sector, while other exhibit a bioactive behaviour; bioactive

83 polysaccharides are capable of eliciting physiological activities from the molecular to the

84 organismal level ( ). More recent studies showed that a novel bacterium, Paracoccus

85 zeaxanthinifaciens subsp. payriae isolated from a microbial mat (biofilm-like communities)

86 produced bioactive exopolysaccharides with high sulfate content (Raguenes et al. 2004), while a

87 psychrophilic Pseudoalteromonas species isolated from sea-ice microbial communities in the

88 Antarctic, produced a highly anionic extracellular polymers (EPS) (Mancuso et al. 2004). A

89 common feature of these studies is that they have been carried out using bacteria isolated from

90 biofilm communities exposed to extreme conditions. These studies have hypothesized that

91 environmental stress such as high barostatic pressure, large temperature gradients and high

92 salinity, among other factors, select for novel microorganisms capable of producing unusual

93 exopolysaccharides. 
95 On the other hand, limited bioprospecting efforts have been undertaken to isolate novel

96 exopolysaccharide-producing microorganisms from other non-previously recognized extreme

97 marine habitats. Intertidal rocky shores are exposed to a combination of harsh factors such as

98 wave action, thermal and desiccation stress, UV exposure and nutrient depletion (Menge and

99 Branch 2001). Desiccation appears to induce the production of copious amounts of exopolymers,

100 presumably of a highly hygroscopic nature, by biofilms as an ecological strategy to cope with this

101 type of stress (De Winder et al. 1990; Potts 1994; Ortega-Morales et al. 2001). Since atmospheric

102 exposure of intertidal habitats after emersion also produces desiccation stress on extant microbial

103 communities, it is reasonable to hypothesize that these habitats are likely to harbour diverse

104 bacteria capable of producing polysaccharides. Despite their importance, however, to our

105 knowledge only one report has been published to date describing the potential of intertidal

106 bacteria as exopolymer-producers (Boyle and Reade 1983). Here we report the results of a partial

107 chemical characterisation of EPS produced by intertidal biofilm bacteria isolated from a range of

108 natural and artificial surfaces exposed to a subtropical intertidal rocky shore in southern Gulf of

109 Mexico (Campeche, Mexico), a more detailed chemical study of selected polymers, along with

110 the molecular identification of the producing isolates.

111

\section{MATERIALS AND METHODS}

\section{Isolation of bacteria}

114 Leaves of the seagrass Thalassia testudinum, copper coupons and rock samples were collected

115 from a pristine rocky intertidal shore in the State of Campeche, Southern Gulf of Mexico. This

116 type of shore is common in the Yucatan Peninsula. Samples of leaves and rock chips showing

117 heavy biofilm growth were aseptically recovered in sterile plastic bags, chilled on ice and 
118 transported to the laboratory. Copper coupons $\left(2 \mathrm{~cm}^{2}\right)$ were treated following the same procedure,

119 except that these coupons were placed $15 \mathrm{~d}$ before the sampling period to allow for biofilm

120 development. Copper is a bioactive substratum shown to select for exopolymer-producing

121 microorganisms (Marszalek et al. 1979; Guezennec 2002). Once in the laboratory, the samples

122 were gently washed with sterile seawater to remove loosely attached bacteria and placed in $10 \mathrm{ml}$

123 of sterile seawater and vortexed for one minute to obtain cell suspensions. These suspensions

124 were serially diluted and plated on Marine Agar (MA, Difco Laboratories, Detroit, MI). Plates

125 were then incubated at $30^{\circ} \mathrm{C}$ for $5 \mathrm{~d}$ and checked daily to pick by a random procedure

126 representative colonies which were then successively restreaked for purification. Isolates were

127 checked by microscopy and although this procedure does not ensure pure cultures nor allows

128 dereplication of isolates, it has been used successfully in the past to obtain pure

129 exopolysaccharide-producing bacterial isolates. Strains were preserved as glycerol suspensions

$130(20 \%, \mathrm{w} / \mathrm{v})$ at $-80^{\circ} \mathrm{C}$. Working cultures were maintained on Marine Agar 2216 slants at $4^{\circ} \mathrm{C}$.

131

\section{Screening for EPS synthesis}

133 In a first screening, thirty-four strains were screened for their ability to synthesize EPS in Marine 134 agar $2216(\mathrm{MA})$ plates amended with 3\% (w/v) glucose (MA + $3 \%$ glucose). Calibrated loops

135 were used to streak $\sim 30 \mu \mathrm{l}$ of overnight cultures (grown on MB) on MA $+3 \%$ glucose plates. The

136 plates were incubated at $30^{\circ} \mathrm{C}$ for $48 \mathrm{~h}$. Mucoid (slimy) colonies, indicative of their ability to

137 produce exopolymeric substances (De Vuyst and Degeest 1999; Fusconi and Godinho 2002;

138 Maugeri et al. 2002), were selected for further screening. Control cultures were performed with

139 MA plates without the glucose amendment (Raguenes et al. 1997). 
141 In a second step, the presumably EPS-producing strains (11 isolates) were reinoculated $(\sim 30 \mu \mathrm{l})$

142 on MA + 3\% glucose plates and incubated as described above. A marine biofilm forming

143 bacterium Halomonas marina CCUG16095 obtained from the Culture Collection, University of

144 Göteborg, Sweden, was used a positive control organism. This bacterium has been shown to

145 produce significant concentrations of EPS in agar and liquid cultures (Ford and Mitchell 1992;

146 Chan-Bacab and Ortega-Morales 2005). The bacterial biomass was then carefully scraped from

147 the agar surface by means of a spatula and split in two aliquots. One aliquot was used to

148 determine wet weight, while the remaining fraction was transferred to a tube containing $5 \mathrm{ml}$ of

$1493.5 \% \mathrm{NaCl}$ solution $(\mathrm{w} / \mathrm{v})$. This latter fraction containing the bacterial suspension was then

150 vortexed for $5 \mathrm{~min}$ and centrifuged at $10,000 \mathrm{x} g$ for $5 \mathrm{~min}$. The cell pellet was discarded and the

151 supernatant was then mixed with two volumes of cold absolute ethanol. The precipitated EPS

152 fraction was assayed using the Dubois method with glucose as standard. The content of

153 polysaccharides per unit dry weight of bacterial biomass was then determined, assuming a 95\%

154 water content in biofilms (Zhang et al. 1998).

156 Production and preliminary chemical characterisation of exopolymers.

157 After the screening procedure, 7 strains were retained for exopolymer (EPS) production, from

158 which four isolates were selected on the basis of the highest amount of polysaccharide produced

159 per unit colonial biomass on marine agar plates (MC1B-03, MC3B-10, MC6B-28 and MC1B-

160 32), while three additional bacterial isolates (MC6B-02, MC3B-13 and MC6B-22) were also

161 studied since they showed good growth in MB (Table 1). EPS production was performed at $30^{\circ} \mathrm{C}$

162 in 1-1 Erlenmeyer flasks containing $500 \mathrm{ml}$ of marine broth amended with glucose $\left(30 \mathrm{~g} \mathrm{l}^{-1}\right)$.

163 Batch fermentation was started by inoculating $50 \mathrm{ml}$ of a suspension of cells grown overnight in

164 the same culture medium. The flasks were then shaken at $200 \mathrm{rpm}$ (LAB-LINE Instruments, INC, 
$165 \mathrm{IL}, \mathrm{USA}$ ) at $30^{\circ} \mathrm{C}$ for $48 \mathrm{~h}$. Bacterial growth was determined spectrophotometrically at $520 \mathrm{~nm}$

166 from aliquots that were removed at regular intervals.

168 After the cultures reached the exponential phase of growth (24-36 h), culture broths were heated

169 at $100^{\circ} \mathrm{C}$ for $15 \mathrm{~min}$ to inactivate the enzymes capable of degrading the polymer (Cerning et al.

170 1994). Cells were then removed by centrifugation at $4,000 \times \mathrm{g}$ for $30 \mathrm{~min}$ at $4{ }^{\circ} \mathrm{C}$ and filtered

171 through $0.47 \mu \mathrm{m}$ pore diameter HVLP filters. The supernatant was allowed to stand overnight at

$1724^{\circ} \mathrm{C}$; the EPS were then precipitated by adding 2 volumes of cold absolute ethanol. The EPS were

173 collected by centrifugation $4,000 \times \mathrm{g}$ for $30 \mathrm{~min}$ at $4{ }^{\circ} \mathrm{C}$ and redissolved in a small volume of

174 distilled water, to repeat the precipitation procedure as described above. It was subsequently

175 dialyzed (molecular weight cut-off 6,000 to 8,000 Da) against deionized water for $48 \mathrm{~h}$,

176 reprecipitated and dried at $40^{\circ} \mathrm{C}$ and estimated gravimetrically. Protein content was determined

177 following the method proposed by Lowry et al. (1951) using albumin as the standard protein.

178 Hexuronic acid concentrations were determined by the $m$-phenylphenol method (Blumenkrantz

179 and Asboe-Hansen 1973), with glucuronic acid as the standard, while total neutral carbohydrate

180 content was determined by the orcinol-sulfuric method (Tillmans and Philippi 1929; Rimington

181 1931) using a standard of a 1:1 molar ratio mixture of mannose-galactose.

183 Given the anionic composition of polymers produced by strains MC3B-10 and MC6B-22, as

184 revealed by colorimetric analyses, their monosaccharide composition was determined as

185 described below. The producing bacterial isolates were identified by sequencing of 16S rDNA

186 and whole cellular fatty acid analyses. Since only the isolate MC3B-10 yielded relatively high

187 concentration of polymer in our laboratory conditions $\left(\sim 2 \mathrm{~g} \mathrm{l}^{-1}\right)$, the surfactant activity and

188 additional spectroscopic analyses were performed on this single polymer. 
190 Characterization of EPS MC3B-10 and MC6B-22

191 Monosaccharide composition. The monosaccharides were analysed after hydrolysis by acid 192 methanolysis of the polymers with $\mathrm{MeOH} / \mathrm{HCl}(2 \mathrm{~N})$ during $4 \mathrm{~h}$ at $100^{\circ} \mathrm{C}$ and subsequent $\mathrm{GC}$

193 analyses of peracetylated derivatives of trimethyl-sylil derivatives. Erythritol was used as internal

194 standard. The analytical procedure was performed using a Fisons instrument (GC 8000 series)

195 fitted with a WCOT fused silica CP-SIL 5CB $(60 \mathrm{~m} \times 0.25 \mathrm{~mm})$ with a temperature gradient from

$19650^{\circ} \mathrm{C}$ to $120^{\circ} \mathrm{C}$ (at $20^{\circ} \mathrm{C} \mathrm{min}^{-1}$ ) and from $120^{\circ} \mathrm{C}$ to $250^{\circ} \mathrm{C}\left(\right.$ at $2^{\circ} \mathrm{C} \mathrm{min}^{-1}$ ) and hydrogen as carrier

197 gas. The molar ratios of monosaccharides were determined according to Kamerling et al. (1975)

198 and Montreuil et al. (1986).

200 Assessment of surfactant activity. The surfactant activity of EPS MC3B-10 was determined as

201 previously reported (Bouchotroch et al. 2000). Briefly, equal volumes of EPS solutions [1\%

$202(w / v)$ in deionized water] and aliphatic hydrocarbons of increasing carbon chain length were

203 added to 12-mm-diameter glass tubes and vigorously mixed using a vortex. The tubes were

204 allowed to stand for $24 \mathrm{~h}$. Surfactant activity was expressed as the percentage of the total height

205 occupied by the emulsion. The hydrocarbons ( $n$-hexane, $n$-octane and $n$-hexadecane) and control

206 surfactants (Tween 80 and Triton X-100) were purchased from Sigma (St. Louis, MO).

208 X-ray Photoelectron (XPS) and Fourier Transform Infrared Spectroscopy analyses. Fourier

209 transform infrared spectroscopic analysis (FT-IR) was performed according to Suci et al. (1997).

210 Spectra were acquired with a $4 \mathrm{~cm}^{-1}$ resolution in the $4000-400 \mathrm{~cm}^{-1}$ region, using a Nicolet

211 Magna 460 FTIR spectrometer with a deuterade triglycine sulfate (DTGS) detector in the 
212 transmission mode. Compressed tablets were prepared by mixing $2 \mathrm{mg}$ of EPS with $100 \mathrm{mg}$ of

$213 \mathrm{KBr}$. Spectra were corrected for KBr background using the OMNIC software.

215 XPS analyses were performed in a Perkin-Elmer PHI 560/ESCA-SAM system, equipped with a

216 double-pass cylindrical mirror analyzer, with a base pressure of $1 \times 10^{-9}$ Torr. Argon ion sputtering

217 was performed with $4 \mathrm{keV}$ energy ions and $0.36 \mu \mathrm{A} / \mathrm{cm}^{2}$ current beam, yielding to about 3

$218 \mathrm{~nm} / \mathrm{min}$ sputtering rate. All XPS spectra were obtained after $5 \mathrm{~min}$ of $\mathrm{Ar}^{+}$sputtering. The utilized

219 low current density in the ion beam and short cleaning time reduce possible drastic modifications

220 in the stoichiometry of the surface. For the XPS analyses, sample was excited with $1486.6 \mathrm{eV}$

221 energy AlK $\alpha$ X-ray. XPS spectra were obtained under two different conditions: (i) a survey

222 spectrum mode of 0-600 eV, and (ii) a multiplex repetitive scan mode. No signal smoothing was

223 attempted and a scanning step of $1 \mathrm{eV} / \mathrm{step}$ and $0.2 \mathrm{eV} / \mathrm{step}$ with an interval of $50 \mathrm{~ms}$ was utilized

224 for survey and multiplex modes, respectively. The spectrometer was calibrated using the $\mathrm{Cu}$

$2252 \mathrm{p} 3 / 2(932.4 \mathrm{eV})$ and $\mathrm{Cu} 3 \mathrm{p} 3 / 2(74.9 \mathrm{eV})$ lines. Binding energy calibration was based on $\mathrm{C} 1 \mathrm{~s}$ at $226 \quad 284.8 \mathrm{eV}$.

228 Bacterial identification

229 16S rDNA sequence analysis. The 16S rDNA genes of isolates MC3B-10 and MC6B-22 were

230 analysed. DNA was extracted, using the Wizard Genomic DNA Purification kit, according to the

231 manufacturer's protocol (Promega). The 16S rDNA gene was amplified by PCR using universal

232 primers Fd1 (5'-CAGAGTTTGATCCTGGCTCAG-3') and R6 (5'-

233 TACGGTTACCTTGTTACGAC-3') for strain MC3B-10 and the primers Fd1 and Rd1 (5'-

234 AAGGAGGTGATCCAGCC-3') (Winker and Woese 1991) for strain MC6B-22. The PCR 
235 mixture contained $50 \mu \mathrm{l}$ final volumen: $5.0 \mu \mathrm{l}$ of $10 \mathrm{X}$ buffer, $5 \mu \mathrm{l}$ of $25 \mathrm{mM} \mathrm{MgCl}, 0.5 \mu 1$ of 10

$236 \mathrm{mmol} \mathrm{l}^{-1} \mathrm{dNTP}$ mixture, $0.5 \mu \mathrm{l}$ of a $50 \mathrm{pmol} \mu \mathrm{l}^{-1}$ solution of each primer, $0.5 \mu \mathrm{l}$ of Taq

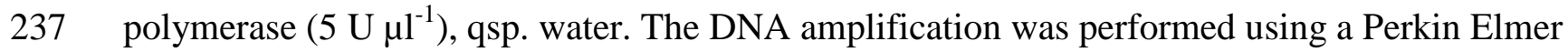

238 Gene Amp PCR, System 2400. The PCR program was as follows: $95^{\circ} \mathrm{C}$ for $1 \mathrm{~min}, 30$ cycles of

$23920 \mathrm{~s}$ at $95^{\circ} \mathrm{C}, 30 \mathrm{~s}$ at $55^{\circ} \mathrm{C}, 1.30 \mathrm{~min}$ at $72^{\circ} \mathrm{C}$, and final extension of $5 \mathrm{~min}$ at $72^{\circ} \mathrm{C}$. PCR products

240 were visualized under UV light after electrophoresis on a $0.8 \%(\mathrm{w} / \mathrm{v})$ agarose gel containing

241 ethidium bromide. PCR products were cloned using the pGEM-T-easy cloning kit and chemically

242 competent Escherichia coli JM109 cells, according to the manufacturer's protocol (Promega).

243 The clone library was screened by direct PCR amplification from a colony using the vector

244 specific primers SP6 (5'-ATTTAGGTGACACTATAGAA-3') and T7 (5'-

245 TAATACGACTCACTATAGGG-3') and the same reaction conditions as described above, was

246 used. A plasmid containing the right length insert was isolated using the kit Wizard Plus SV

247 Minipreps DNA Purification System (Promega) as described in the protocol. Purified plasmids

248 were sent for sequencing to Genome Express (Grenoble, France).

250 Sequence analysis. The nucleotide sequences of the 16S rDNA genes (about 1400 nucleotides

251 each) were aligned using Clustal W program, version 1.5 (Thompson et al. 1994) and then

252 manually adjusted. Reference sequences were obtained from the Ribosomal Database Project

253 (Maidak et al. 2001) and GenBank database (Benson et al. 1999). Positions of sequence and

254 alignment uncertainty were omitted from the analysis. Phylogenetic inference was obtained by

255 using a Bayesian approach, a model-based phylogenetic method, as implemented in MRBAYES

256 3.01. This program uses the Bayes theorem and the models of Monte Carlo Markov Chains

257 (MCMC) and the General Time Reversible (GTR) nucleotide substitution model (Huelsenbeck

258 and Ronquist 2001). The analysis was run for $1 \times 10^{6}$ generations and the trees sampled after 
259 reaching chain stationary (the "burn-in") were used in a majority-rule consensus tree. Full $16 \mathrm{~S}$

260 rDNA sequences of 2 isolates were deposited into the GenBank database under the accession

261 numbers AY833570 (MC3B-10) and AY833573 (MC6B-22).

263 Cellular fatty acid methyl ester (FAME) analysis. These strains were grown and the

264 phospholipids were extracted and derivatized for FAME analysis using gas-liquid

265 chromatography following the manufacturers' instructions (Sherlock Microbial Identification

266 System; MIDI, Inc., Newark, Del.).

268 RESULTS

\section{Screening of EPS-producing bacterial isolates}

270 A total of 34 bacterial isolates, randomly taken from MA plates inoculated with different types of

271 biofilms from an intertidal tropical rocky shore, were screened for EPS production on both

272 Marine Agar (MA) and MA amended with glucose (MA + glucose). Most of the mucoid isolates

273 were obtained from epilithic (rock surface) biofilms. Out of these 34 isolates, 11 strains

274 developed as mucoid colonies; this was particularly the case of colonies grown on MA + glucose.

275 These 11 isolates were obtained from copper surfaces (41\%), epilithic biofilms (27\%) and

276 epiphytic biofilms (27\%), respectively.

278 Seven isolates (MC6B-02, MC1B-03, MC3B-10, MC3B-13, MC6B-22, MC6B-28 and MC1B-

279 32) showed a more abundant growth on agar plates than the rest of the isolates and/or grew well 
280 in liquid medium. No correlation was seen between isolates exhibiting good growth in MA plates

281 and marine broth (Table 1).

282

283 These isolates synthesized varying concentrations of EPS, whose chemical composition also

284 varied (Table 2). Protein levels were in general high, except for strain MC6B-22 (8.9\%). Neutral

285 sugars also tended to dominate in the sugar profiles of EPS from most isolates. Significant

286 concentrations of acid sugars were seen in EPS from isolate MC3B-10 (9.1\%) and MC6B-22

287 (14.7\%). Hexosamine content was highly variable among the isolates, but strain MC6B-22

288 produced an exopolysaccharide with unusually high concentrations of this monosaccharide $289(21.1 \%)$.

\section{Bacterial identification}

292 The identification of isolates MC6B-22 and MC3B-10 was carried out using both 16S rDNA

293 sequencing and whole-cell fatty acid analyses. Both isolates were Gram positive organisms that

294 displayed mucoid colonial phenotypes. Strain MC3B-10 displayed a strong orange pigmentation

295 when grown on MA plates. However, an enhanced phenotype of the colonies exhibiting an even

296 stronger pigmentation, were seen when they were grown on plates of MA amended with glucose.

297 In turn, isolate MC6B-22 produced opaque, irregular colonies.

299 Phylogenetic analysis based on the 16S rDNA sequences placed these strains as members of the 300 genus Microbacterium (MC3B-10) and Bacillus (MC6B-22). Strain MC3B-10 was closely

301 related to Microbacterium trichotecenolyticum, M. flavescens and M. kitamense (Fig. 1), with

302 similarity values ranging from 97 to $99 \%$. On the other hand, isolate MC6B-22 was identified as 
303 a close relative of Bacillus mojavensis and B. subtilis (Fig. 2), with similarity values up to $99 \%$.

304 Definitive identification of these isolates will require quantitative DNA-DNA hybridization 305 analysis (Raguenes et al. 2004).

307 Characterization of exopolymers

308 The screening of isolates implemented in this study showed that strains MC3B-10 and MC6B-22

309 presented the most interesting properties. Therefore, they were retained for further

310 characterization studies. GC analysis of monosaccharides as per- $O$-trimethylsilyl

311 methylglycosides of these polymers is given in Table 3. Glucose predominated in the neutral

312 sugar fraction of both polymers, although this sugar represented a higher proportion (25\%) of the

313 total monosaccharides in the EPS MC3B-10. Lower levels of galactose and mannose were

314 detected in both EPS. Rhamnose was found only in EPS MC3B-10 in small amounts. Both

315 polymers possessed uronic acids (galacturonic acid and glucuronic acid) and hexosamines $(\mathrm{N}$ -

316 acetyled glucosamine), but the concentrations of the latter compound were significantly higher in

317 the EPS synthesized by isolate MC6B-22.

319 The FTIR spectrum of the polymer produced by isolate Microbacterium sp. MC3B-10 displayed

320 a broad $\mathrm{O}-\mathrm{H}$ stretching band at $3421 \mathrm{~cm}^{-1}$ and at an intense band at $1070 \mathrm{~cm}^{-1}$, typical of

321 carbohydrates. In addition, bands at 1650 and $1550 \mathrm{~cm}^{-1}$ were also detected. No doublet at 1250

322 and $1230 \mathrm{~cm}^{-1}$, indicative of the presence of ester sulfate groups, was seen (Fig. 3). On the other

323 hand, the XPS spectrum (Fig. 4) of this polymer shows the $\mathrm{O} 1 \mathrm{~s}(533 \mathrm{eV}), \mathrm{N} 1 \mathrm{~s}(401 \mathrm{eV}), \mathrm{Ca}$

$3242 \mathrm{p} 3 / 2(349 \mathrm{eV})$ and $\mathrm{C} 1 \mathrm{~s}(287 \mathrm{eV})$ as core level principal peaks. Also, Ca 2s (441 eV), Ca 3s (46

$325 \mathrm{eV})$ and $\mathrm{Ca} 3 \mathrm{p}(27 \mathrm{eV})$ secondary peaks were detected. 
327 EPS MC3B-10 was shown to exhibit surfactant activity against aliphatic hydrocarbons. This

328 polymer exhibited a higher activity than commercial surfactants such as Triton X-100 and Tween

329 80. This trend was more evident with hydrocarbons of long chain length ( $n$-hexadecane) than

330 with short-chained hydrocarbons ( $n$-hexane; Fig. 5).

331

\section{DISCUSSION}

333 This study expands our knowledge on the ability of intertidal bacteria to synthesize EPS, since a

334 previous study reported only EPS-producing bacterial from cold coasts (Boyle and Read 1983).

335 Most of the isolates obtained in this study exhibited mucoid colonial phenotypes, when plated on

336 Marine agar (MA), and presented an enhanced (more) viscous morphology, when grown on MA

337 supplemented with glucose. Two bacterial isolates, identified by $16 \mathrm{~S}$ rDNA sequencing and

338 cellular fatty acid analysis as a Microbacterium species and a Bacillus species, were further

339 selected on the basis of their ability to grow well both in solid (agar) and liquid marine media and

340 because they produced polymers with significant uronic acid and hexosamine levels as indicated

341 by colorimetric analysis.

343 These EPS differed in their chemical composition, as shown by colorimetric and gas

344 chromatographic (GC) analyses. Polymer MC3B-10 had high levels of protein (36\%), a finding

345 confirmed by FTIR data which showed intense bands at 1640 and $1550 \mathrm{~cm}^{-1}$, typical of $\mathrm{C}=\mathrm{O}$

346 stretching in secondary amides (amide I) and $\mathrm{N}-\mathrm{H}$ deformation and $\mathrm{C}-\mathrm{N}$ stretching in - $\mathrm{CO}-\mathrm{NH}-$

347 (amide II) in proteins (Suci et al. 1997; Omoike and Chorover 2004). In contrast, polymer

348 synthesized by isolate Bacillus sp. MC6B-22 had lower amounts of proteins. Another important

349 differing feature between both EPS was the higher concentration of neutral sugars in polymer

350 MC3B-10 and hexosamines ( 10 fold) in polymer MC6B-22. These findings suggest that the 
351 exopolymer produced by the strain MC3B-10 is not a polysaccharide, but a glycoprotein. This is

352 further supported by the detection of significant surfactant activity and because this polymer was

353 not completely soluble in distilled water. Amphipathic molecules including glycoproteins possess

354 surfactant activity that may render them potential candidates for environmental and medical

355 applications (Rosenberg and Ron 1999; Cameotra and Markkar 2004). Reinforcing this finding,

356 XPS analyses showed nitrogen and carbon as dominant elements in the elemental chemical

357 profile. In addition, the N/C ratio was 0.14 , which is close to the reported ratio of 0.16 for a

358 mixture of protein and polysaccharide (Rubio 2002). Interestingly, this analysis also showed that

359 calcium was associated with this polymer. This signal was detected in freeze-dried amorphous

360 polymer samples (Fig. 4) that were exhaustively washed with deionized water. This suggests that

361 this element was sequestered from the bulk culture medium and points toward a likely chelating

362 property, which is congruent with the anionic composition (presence of hexuronic acids) of this

363 EPS, although electron donating moieties such as carbonyls and hydroxyls in polysaccharides

364 may also chelate cations such as $\mathrm{Ca}^{2+}$ (Perry et al. 2004). Although more work is needed to

365 define the chelating properties of this polymer, our finding suggests its application as a new

366 biosorbant (Guezennec et al. 2002).

368 On the other hand, the low levels of protein in polymer MC6B-22 and the considerable amounts

369 of hexuronic acids, especially glucuronic acid and hexosamines (glucosamine- $N$-acetylated and

370 galactosamine- $N$-acetylated) suggest that it is a polysaccharide with promising biomedical

371 activities. Hyaluronic acid (HA) is a polymer naturally found in connective tissue and is

372 composed of a repeating disaccharide unit of $N$-acetylglucosamine and glucuronic acid, that has

373 potential applications in wound healing and angiogenesis (Cen et al.2004). In addition, tissue 
374 regeneration (bone healing) properties have been found in a new hyaluronic acid-like bacterial

375 exopolysaccharide (Zanchetta et al. 2003a; Zanchetta et al. 2003b).

376

377 It is interesting to note that the chemical composition of EPS from both isolates is different from

378 other species from the same genera. Matsuyama et al. (1999) showed that a new Microbacterium

379 species, M. kitamiense produced both soluble and insoluble EPS. Analysis of these EPS showed

380 that they contained neither protein nor uronic acids, significantly differing from the EPS

381 produced by Microbacterium MC3B-10. Similarly, polymer produced by our Bacillus sp. MC6B-

38222 contained aminosugars and uronic acids. In contrast, Mança et al. (1996) reported the

383 synthesis of a sulfated heteropolysaccharide composed exclusively of mannose and glucose in a

384 Bacillus thermoantarcticus strain. This suggests that exopolymer production and composition in

385 biofilms is a species-specific process, although the influence of culture medium cannot be ruled 386 out (Sutherland 2001).

Microbacterium and Bacillus species have been shown to form biofilms and inhabit other marine environments, including sediments, invertebrate tissues (surfaces) and artificial aquacultural

390 ponds (Wicke et al. 2000; Lang et al. 2004). However, the Bacillus isolate MC6B-22 obtained

391 from a biofilm developed on a copper coupon, to our knowledge is the first report of a tropical

392 intertidal bacterium closely related to Bacillus mojavensis and B. subtilis, organisms considered

393 of terrestrial origin. We cannot establish at this point, however, if this bacterium is a true marine

394 bacterial isolate or if it is a transient intertidal colonizer that originated from nearby terrestrial

395 environments. It is also interesting to note that isolate Microbacterium MC3B-10 produced an

396 EPS with significant surfactant activity, which was in fact higher than that exhibited by

397 commercial compounds. These EPS may participate in structuring epilithic biofilms conferring 
398 them mechanical stability (Mayer et al. 1999) and protect bacterial populations from desiccation

399 (De Winder et al. 1990; Potts 1994; Ortega-Morales et al. 2001), ecological roles that are

400 congruent with the stress imposed by intertidal areas (Menge and Branch 2001). In addition,

401 surfactant EPS may also enable the component cells embedded in epilithic biofilms to solubilize

402 and utilize substrates which would otherwise be inaccessible (Sutherland 2001; Ortega-Morales

403 et al. 2001). In a previous study, we showed that significant levels of EPS were found associated

404 with epilithic biofilms in the Gulf of Mexico (Narváez-Zapata et al. 2005).

405

406 Further genetic studies (DNA-DNA hybridization) and chemical (NMR), as well as biological

407 analyses (bioassays) are needed to fully assess the biotechnological potential of polymers MC3B-

40810 and MC6B-22 in particular in biomedical and environmental fields. Also more detailed studies

409 are required to determine the ecological role that these compounds may play in the survival and

410 persistence of these bacteria in naturally occurring intertidal biofilms.

411

412 ACKNOWLEDGEMENTS

413 This research was supported by a CONACYT grant J-33085-B to B.O.O-M. Partial support by research

414 grant from CONACYT (41693-M) to J.C.C. is acknowledged. We thank F. Martínez and Wilian

415 Cauich for technical assistance in phylogenetic and XPS analyses, respectively. We are also

416 indebted to the reviewers whose suggestions helped improve this manuscript. 


\section{REFERENCES}

423 Benson, D.A., Boguski, M.S., Lipman, D.J., Ostell, J., Ouellette, B.F.F., Rapp, B.A. and

424 Wheeler, D. (1999) GenBank. Nucleic Acids Res 27, 12-17.

425

426 Bouchotroch, S., Quesada, E., Izquierdo, I., Rodríguez, M. and Béjar, V. (2000) Bacterial

427 exopolysaccharides produced by newly discovered bacteria belonging to the genus Halomonas

428 isolated from hypersaline habitats in Morocco. J Ind Microbiol Biotechnol 24, 374-378.

429

430 Boyle, C.D. and Reade, A.E. (1983) Characterization of two extracellular polysaccharide marine 431 bacteria. Appl Environ Microbiol 46, 392-399.

432

433 Blumenkrantz, N. and Asboe-Hansen, G. (1973) New method for quantitative determination of 434 uronic acids. Anal Biochem 54, 484-489.

435

436 Cameotra, S.S. and Makkar, R.S. (2004) Recent applications of biosurfactants as biological and 437 immunological molecules. Curr Opin Microbiol 7, 262-266.

438

439 Cen, L., Neoh, K.G., Li, Y. and Kang, E.T. (2004) Assessmentof in vitro bioactivity of

440 hyaluronic acid and sulfated hyaluronic acid functionalized electroactive polymer. Biomacromol $441 \quad 5,2238-2246$.

442

443 Cerning, J., Renard, C.M.G.C., Thibault, J.F., Bouillanne, C., Landon, M., Desmazeaud, M. and 444 Topisirovic. L. (1994) Carbon source requirements for exopolysaccharide production by 
445 Lactobacillus casei CG11 and partial structure analysis of the polymer. Appl Environ Microbiol $446 \quad 60,3914-3919$.

447 Chan-Bacab, M.J. and Ortega-Morales, B.O. (2005) Antifouling activity of biofilm bacteria 448 isolated from an intertidal environment in the Gulf of Mexico. In Labs 5 Biodeterioration and 449 Biodegradation in Latin America ed. Ortega-Morales, B.O., Gaylarde, C.C., Narvaez-Zapata, 450 J.A. and Gaylarde, P.M. p. 65-70. Campeche, Mexico: Universidad Autónoma de Campeche y 451 CINVESTAV.

452 Costerton, J.W., Irvin, R.T. and Cheng, K.J. (1981) The bacterial glycocalyx in nature and 453 disease. Аппи Rev Microbial 35, 299-324.

455 De Vuyst, L. and Degeest, B. (1999) Heteropolysaccharides from lactic acid bacteria. FEMS 456 Microbiol Rev 23, 153-177.

457

458 De Winder, B., Matthijs, H.C.P. and Mur, L.R. (1990) The role of water retaining substrata on 459 the photosynthetic reponse of three drought tolerant phototrophic microorganisms isolated from a 460 terrestrial habitat. Arch Microbiol 152, 458-462.

462 Felstein, J. (1985) Confidence limits on phylogenies: an approach using the bootstrap. Evolution 463 39, 783-791. 
465 Flemming, H.C., Wingender, J., Moritz, R., Borchard, W. and Mayer, C. (1999) Physico-

466 chemical properties of biofilms-A short review. In Biofilms in the Aquatic Environment ed.

467 Keevil, C.W., Godfree, A., Holt, D. and Dow, C. pp. 1-12. Cambridge, UK: The Royal Society of

468 Chemistry.

469

470 Ford, T. and Mitchell, R. (1992) Microbial transport of trace metals. In Environmental

471 Microbiology ed. Mitchell, R. pp. 83-101. New York: Wiley-Liss.

472

473 Fusconi, R. and Godinho, M.J.L. (2002) Screening for exopolysaccharide-producing bacteria

474 from sub-tropical polluted groundwater. Braz J Biol 62, 363-369.

475

476 Guezennec, J., Ortega-Morales, O., Raguenes, G. and Geesey, G. (1998) Bacterial colonization of

477 artificial substrate in the vicinity of deep-sea hidrothermal vents. FEMS Microbiol Ecol 26, 89-

478100.

479

480 Guezennec, J. (2002) Deep-sea hydrothermal vents: A new source of innovative bacterial

481 exopolysaccharides of biotechnological interest? J Ind Microbiol and Biotechnol 29, 204-208.

482

483 Hall, T.A. (1999) BioEdit: a user-friendly biological sequence alignment editor and analysis 484 program for Windows 95/98/NT. Nucleic Acids Symp Ser 41, 95-98. 
Huelsenbeck, J.P. and Ronquist, F. (2001) MRBAYES: Bayesian inference of phylogenetic trees. Bioinformatics 17, 754-755.

491

492 Kamerling, J.P., Gerwig, G.J., Vliegenthart, J.F.G. and Clamp, J.R. (1975) Characterization by 493 gas-liquid chromatography-mass spectrometry and proton-magnetic-resonance spectroscopy of

494 pertrimethylsilyl glycosides obtained in methanolysis of glycoproteins and glycopeptides.

495 Biochem J 151, 491-495.

497 Lang, S., Beil, W., Tokuda, H., Wicke, C. and Verena, L. (2004) Improved production of 498 bioactive glucosylmannosyl-glycerolipid by sponge associated Microbacterium species. Mar 499 Biotechnol 6, 152-156.

501 Lijour, Y., Gentric, E., Deslandes, E. and Guezennec, J. (1994) Estimation of the sulfate content 502 of hydrothermal vent bacterial polysaccharides by Fourier Transform Infrared Spectroscopy. Anal 503 Biochem 220, 1-5

505 Lowry, O., Rosebroug, H., Farr, A. and Randall, R. (1951) Protein measurement with the Folin506 phenol reagent. J Biol Chem 193, 265-275. 
508 Magalhães, C.M., Bordalo, A.A. and Wiebe, W.J. (2003) Intertidal biofilms on rocky substratum

509 can play a major role in estuarine carbon and nutrients dynamics. Mar Ecol Prog Ser 258, 257-

510281.

511

512 Maidak, B.L., Cole, J.R., Lilburn, T.G., Parker Jr., C.T., Farris, R.J., Garrity, G.M., Olsen, G.J.,

513 Schmidt, T.M. and Tiedje, J.M. (2001) The RPD II (Ribosomal database project). Nucleic Acids

514 Res 29, 173-174.

515

516 Mança, M.C., Lama, L., Improta, R., Esposito, E., Gambacorta, A. and Nicolaus, B. (1996)

517 Chemical composition of two exopolysaccharides from Bacillus thermoantarcticus. Appl Environ

518 Microbiol 62, 3265-3269.

519

520 Mancuso, C.A., Garon, S., Bowman, J.P., Raguénès, G. and Guezennec, J. (2004) Production of

521 exopolysaccharides by Antarctic marine bacterial isolates. J Appl Microbiol 96, 1057-1066.

522

523 Marszalek, D.S., Gerchakov, S.M. and Udey, L.R. (1979) Influence of substrate composition on

524 marine microfouling. Appl Environ Microbiol 38, 987-995.

525

526 Matsuyama, H., Kawasaki, K., Yumoto, I. and Shida, O. (1999) Microbacterium kitamiense sp.

527 nov., a new polysaccharide-producing bacterium isolated from the wastewater of a sugar-beet

528 factory. Int J Syst Bacteriol 49, 1353-1357.

529 
530 Maugeri, T.L., Gugliandolo, C., Caccamo, D., Panico, A., Lama, L., Gambacorta, A. and

531 Nicolaus, B. (2002) A halophilic thermotolerant Bacillus isolated from a marine hot spring able 532 to produce a new exopolysaccharide. Biotechnol Lett 24, 515 -519.

534 Mayer, C., Moritz, R., Kirschner, C., Borchard, W., Maibaum, R., Wingender, J. and Flemming, 535 H.C. (1999) The role of intermolecular interactions: studies on model systems for bacterial 536 biofilms. Int J Biol Macromol 26, 3-16.

538 Menge, B.A. and Branch, G.M. (2001) Rocky intertidal communities. In Marine Community 539 Ecology ed. Bertness, M.D., Gaines, S.D. and Hay, M. pp. 221-251. Sunderland, MA: Sinauer 540 Associates.

542 Montreuil, J., Bouquelet, S., Debra, H., Fournet, B., Spick, G. and Strecker, G. (1986)

543 Carbohydrate analysis: A pratical approach. In Glycoproteins ed. Chapelin, M.F. and Kennedy, 544 J.F. pp. 143-204. New York: Oxford University Press, IRL Press.

546 Narváez-Zapata, J., Tebbe, C.C. and Ortega-Morales, B.O. (2005) Molecular diversity and 547 biomass of ephilitic biofims from intertidal rocky shore in the Gulf of Mexico. Biofilms 2, 1-11.

549 Omoike, A. and Chorover, J. (2004) Spectroscopic study of extracellular polymeric substances 550 from Bacillus subtilis: Aqueous chemistry and adsorption effects. Biomacromol 5, 1219-1230. 551 
552 Ortega-Morales, O., López-Cortés, A., Hernández-Duque, G., Crassous, P. and Guezennec, J.

553 (2001) Extracellular polymers of microbial communities colonizing limestone surfaces. Meth Enz

554 336, 331-339.

555

556 Perry, T..D, Duckworth, O.W., McNamara, C.J., Martin S. T. and Mitchell, R. (2004) The effects

557 of the biologically produced polymer alginic acid on macroscopic and microscopic calcite

558 dissolution rates. Environ Sci Technol 38, 3040-3046.

559

560 Potts, M. (1994) Desiccation tolerance of prokaryotes. Microbiol Rev 58, 755-805.

561 Raguenes, G.R., Pignet, P., Gauthier, G., Peres, A., Christen, R., Rougeaux, H., Barbier, G. and

562 Guezennec, J. (1996) Description of a new polymer-secreting bacterium from a deep-sea

563 hydrothermal vent, Alteromonas macleodii subsp fijiensis, and premilinary characterization of the

564 polymer. Appl Environ Microbiol 62, 67-73.

566 Raguenes, G., Christen, R., Guezennec, J., Pignet, P. and Barbier, G. (1997) Vibrio diabolicus sp.

567 nov. a new polysaccharide-secreting organism isolated from a deep-sea hydrothermal vent

568 polychaeta annelid, Alvinella pompejana. Int J Syst Bacteriol 47, 989-995.

569

570 Raguenes, G., Moppert, X., Richert, L., Ratiskol, J., Payri C., Costa, B. and Guezennec, J. (2004)

571 A novel exopolymer-producing bacterium, Paracoccus zeaxanthinifaciens subsp. payriae,

572 isolated from a kopara mat located in rangiroa, an atoll of French Polynesia. Curr Microbiol 49,

$573 \quad 145-151$.

574 
575 Rubio, C. (2002). Comprension des mécanismes d'adheson des biofilms en milieu marin en vue

576 de la concepcion de nouveuax moyens de prevention. Ph. Thesis. University of Paris 6. France.

577 pp. 214.

578

579 Rimington, C. (1931) The carbohydrate complex of serum protein II: Improved method for

580 isolation and redetermination of structure. Isolation of glucosaminodimannose from protein of

581 blood. Biochem J 25, 1062-1071.

582

583 Rosenberg, E. and Ron, E.Z. (1999) Hig- and low-molecular-mass microbial surfactants. Appl

584 Microbiol Biotechnol 52, 154-162.

585

586 Saitou, N. and Nei, M. (1987) The neighbor-joining method: a new method for reconstructing

587 phylogenetic trees. Mol Biol Evol 4, 405-425.

588

589 Stoodley, P., Sauer, K., Davies, D.G. and Costerton, J.W. (2002) Biofilms as complex

590 differentiated communities. Annu Rev Microbiol 56, 187-209.

591

592 Suci, P.A., Siedlecki, K.J., Palmer, R.J., White, D.C. and G. Geesey, G. (1997) Combined light

593 microscopy and attenuated total reflection Fourier transform infrared spectroscopy for integration

594 of biofilm structure, distribution, and chemistry at solid-liquid interfaces. Appl Environ Microbiol

595 63, 4600-4603.

596

597 Sutherland, I.W. (2001) Biofilm exopolysaccharides: a strong and sticky framework.

598 Microbiology 147, 3-9. 
600 Thompson, J.D., Higgings, D.G. and Gibson, T.J. (1994). ClustalW: improving the sensitivity of

601 progressive multiple sequence alignment through sequence weighting, position-specific gap

602 penalties and weight matrix choice. Nucleic Acids Res 22, 4673-4680.

603

604 Thompson, R.C., Roberts, M.F., Norton, T.A. and Hawkins, S.J. (2000) Feast or famine for 605 intertidal grazing intensity and the abundance of microbial sources. Hydrobiologia 440, 357-367. 606

607 Tillmans, J. and Philippi, K. (1929) The Carbohydrate content of the important proteins of 608 foodstuffs and a colorimetric procedure for the determination of nitrogen-free sugar in protein.

609 Biochem Z 215, 36-60.

611 Vincent, P., Pignet, P., Talmont, F., Bozzi, L., Fournet, B., Milas, M., Guezennec, J., Rinaudo,

612 M. and Prieur, D. (1994). Production and characterization of an exopolysaccharide excreted by a

613 deep-sea hydrothermal vent bacterium isolated from the polychaete Alvinella pompejana. Appl

614 Environ Microbiol 60, 4134-4141.

616 Wicke, C., Hüners, M., Wray, V., Nimtz, M., Bilitewski, U. and Lang, S. (2000) Production and

617 structure elucidation of glycoglycerolipids from a marine sponge-associated Microbacterium 618 species. J Nat Prod 63, 621-626.

619 
620 Winker, S. and Woese, C.R. (1991) A definition of the domain Archaea, Bacteria and Eucarya in 621 terms of small subunit ribosomal RNA characteristics. Syst Appl Microbiol 13, 161-165.

622

623 Zanchetta, P., Lagarde, M. and Guézennec, J. (2003a) A new bone-healing material: A

624 hyaluronic acid-like bacterial exopolysaccharide. Calcif Tissue Int 72, 74-79.

625

626 Zanchetta, P., Lagarde, N. and Guézennec, J. (2003b) Systematic effects on bone healing of a 627 new hyaluronic acid-like bacterial exopolysaccharide. Calcif Tissue Int 73, 232-236.

628

629 Zhang, X.Q., Bishop, P.L. and Kupferle, M.J. (1998) Measurement of polysaccharides and 630 proteins in biofilm extracellular polymers. Wat Sci Tech 37, 345-348.

631 
Table 1 Growth and production of EPS in liquid marine broth (MB) of selected intertidal biofilm bacteria

\begin{tabular}{cccc}
\hline Strain & $\begin{array}{c}\text { Growth on solid medium } \\
(\mu \mathrm{g} \text { polysaccharide } \\
\text { per mg dry weight of } \\
\text { colony biomass })\end{array}$ & $\begin{array}{c}\text { Growth in liquid } \\
\text { medium } \\
(\text { O.D. })\end{array}$ & $\begin{array}{c}\text { EPS yield } \\
\left(\mathrm{mg} \mathrm{l}^{-1}\right)\end{array}$ \\
\hline MC6B-02 & $348 \pm 12^{*}$ & 5.4 & $97.2 \pm 20.9$ \\
MC1B-03 & $768 \pm 12$ & 6.6 & $228.0 \pm 15.8$ \\
MC3B-10 & $672 \pm 48$ & 8.9 & $2229.0 \pm 174.1$ \\
MC3B-13 & $468 \pm 72$ & 13.4 & $190.4 \pm 52.6$ \\
MC6B-22 & $360 \pm 12$ & 7.0 & $344.8 \pm 11.3$ \\
MC6B-28 & $648 \pm 24$ & 2.5 & $195.8 \pm 86.3$ \\
MC1B-32 & $684 \pm 6$ & 1.8 & $152.6 \pm 57.4$ \\
H. marina & $751 \pm 32$ & 7.1 & $1804.0 \pm 58.1$
\end{tabular}

"Means of three determinations \pm S.D.

633

634

635

636

Table 2 Chemical composition of EPS synthesized by intertidal biofilm bacterial isolates.

\begin{tabular}{lcccc}
\hline \multirow{2}{*}{ Isolate } & \multicolumn{4}{c}{ Composition } \\
& \multicolumn{4}{c}{$(\%)$} \\
\cline { 2 - 5 } & Proteins & Neutral sugars & Hexuronic acids & Hexosamines \\
\hline MC6B-02 & $26.41 \pm 4.2^{*}$ & $32.81 \pm 2.9$ & $2.59 \pm 0.5$ & $8.54 \pm 3.1$ \\
MC1B-03 & $43.50 \pm 2.9$ & $40.44 \pm 4.9$ & $2.53 \pm 0.2$ & $7.58 \pm 0.0$ \\
MC3B-10 & $36.17 \pm 2.8$ & $45.02 \pm 3.9$ & $9.10 \pm 1.6$ & $2.65 \pm 1.0$ \\
MC3B-13 & $46.98 \pm 3.5$ & $22.01 \pm 3.3$ & $2.44 \pm 0.0$ & $9.97 \pm 2.1$ \\
MC6B-22 & $8.90 \pm 3.2$ & $5.56 \pm 2.2$ & $14.67 \pm 2.0$ & $21.15 \pm 7.5$ \\
MC6B-28 & $23.62 \pm 5.7$ & $32.74 \pm 3.9$ & $1.23 \pm 0.1$ & $15.15 \pm 5.5$ \\
MC1B-32 & $25.64 \pm 2.4$ & $31.80 \pm 17.6$ & $1.75 \pm 1.2$ & $1.50 \pm 1.4$
\end{tabular}

*Means of three determinations \pm S.D.

640 Table 3 Monosaccharide composition (molar ratios) of the polymers produced by isolates Microbacterium sp. 641 MC3B-10 and Bacillus sp. MC6B-22.

\begin{tabular}{lcccccccc}
\hline Isolate & Man & GlcUA & GalUA & Gal-N-Ac & Glc-N-Ac & Glc & Rha & Gal \\
\hline MC3B-10 & 6.6 & 3.7 & 3.6 & - & 3.7 & 25.8 & 1.7 & 9.6 \\
MC6B-22 & 3.1 & 6.8 & 1.1 & 7.8 & 4.0 & 4.7 & - & - \\
\hline
\end{tabular}




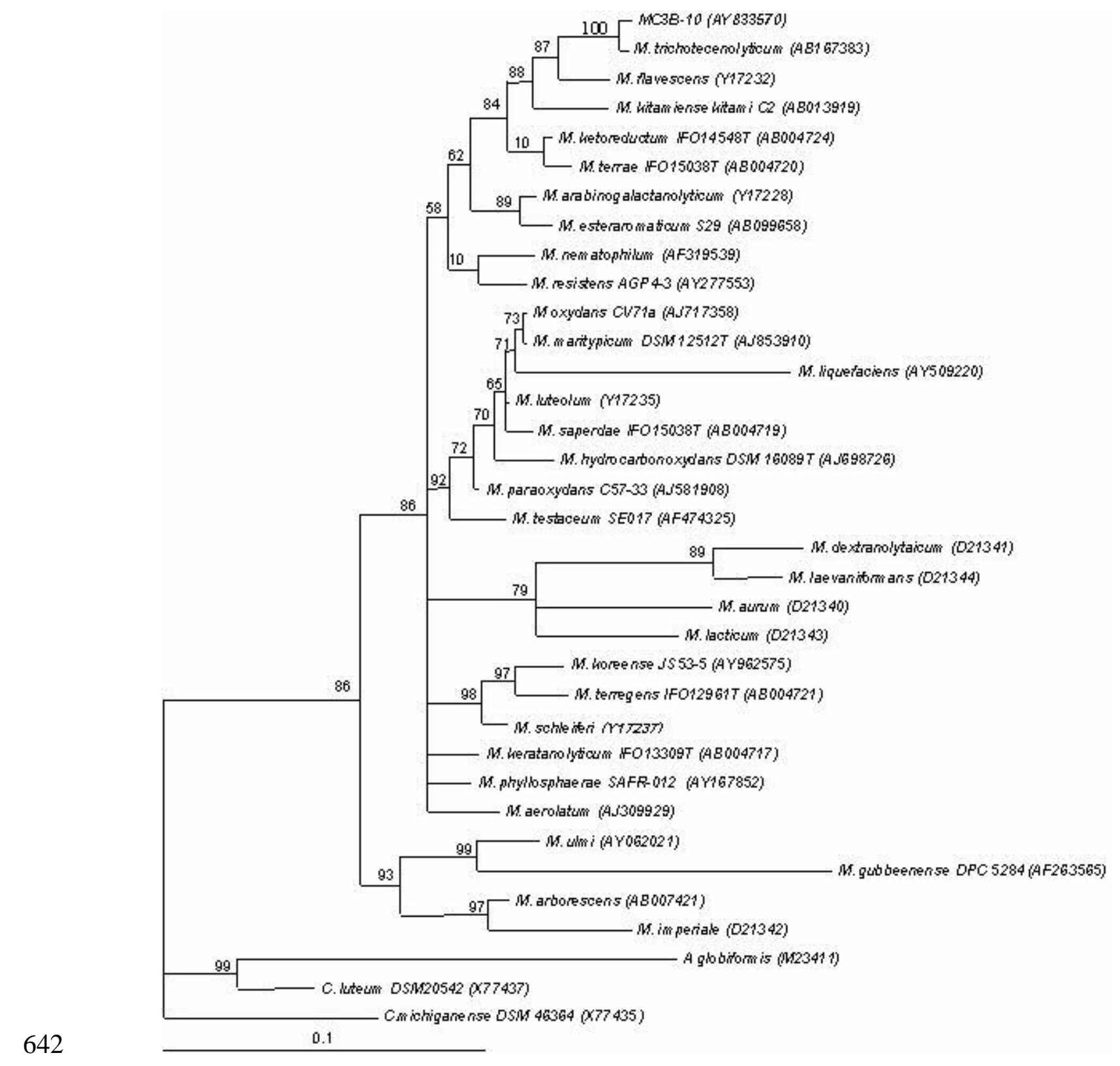

643

645 Fig. 1 Majority rule consensus tree showing the results from Bayesian analysis based on 16S rDNA sequence data,

646 indicating the position of isolate MC3B-10 (AY833570) among members of the genus Microbacterium. Accession

647 numbers of 16S rDNA gene sequences of reference organisms are shown in parenthesis. Numbers above the

648 branches denote posterior probabilities to percentage converted. Branches with a posterior probability of $<0.5$ have

649 been collapsed. Curtobacterium luteum and C. michiganense were used as outgroups. 


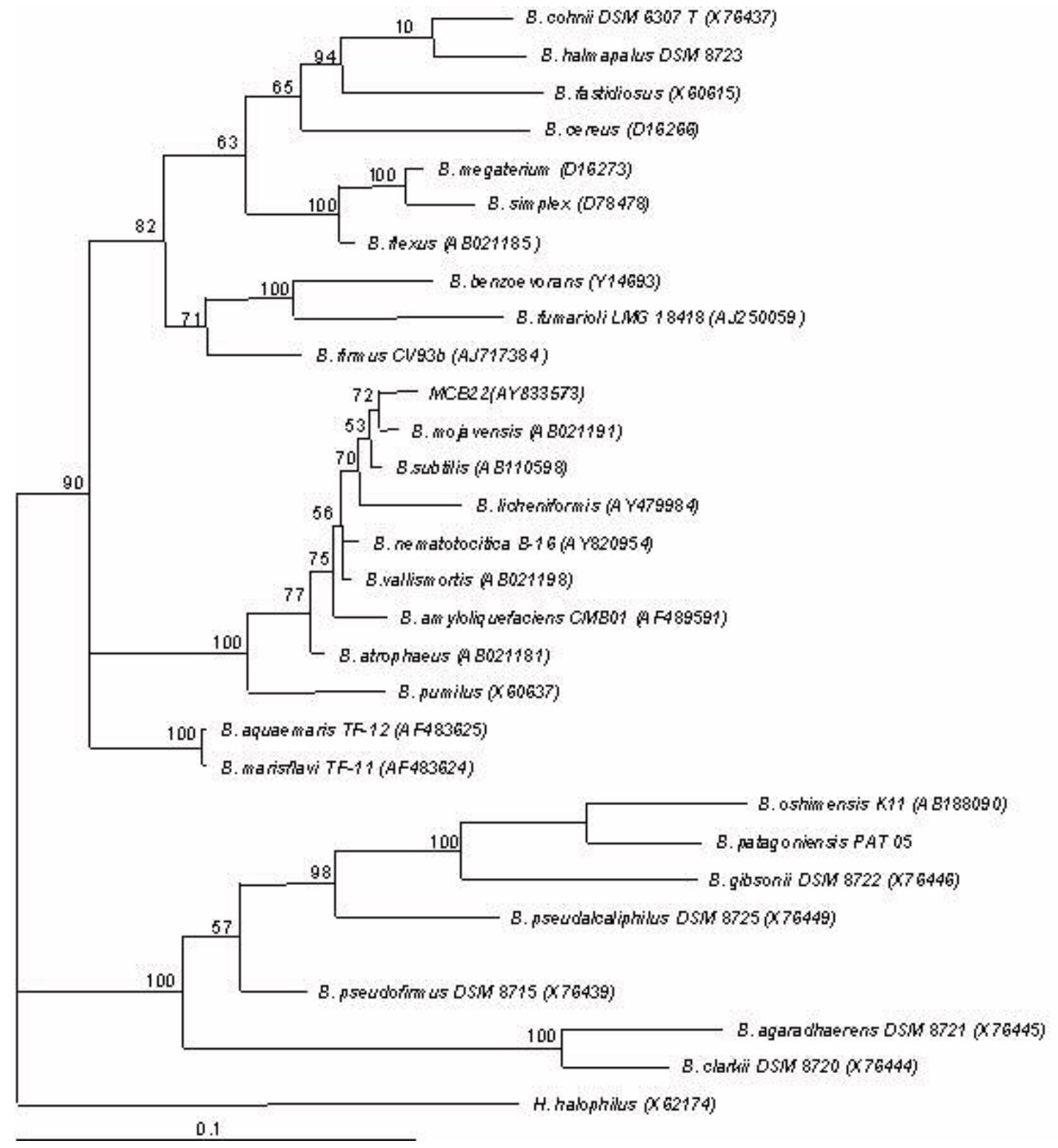

653

654 Fig. 2 Majority rule consensus tree showing the results from Bayesian analysis based on 16S rDNA sequence data, 655 indicating the position of isolate MCB22 (AY833573) among members of the genus Bacillus. Accession numbers of $65616 \mathrm{~S}$ rDNA gene sequences of reference organisms are shown in parenthesis. Numbers above the branches denote 657 posterior probabilities to percentage converted. Branches with a posterior probability of $<0.5$ have been collapsed. 658 Halobacillus halophilus was used as outgroup. 


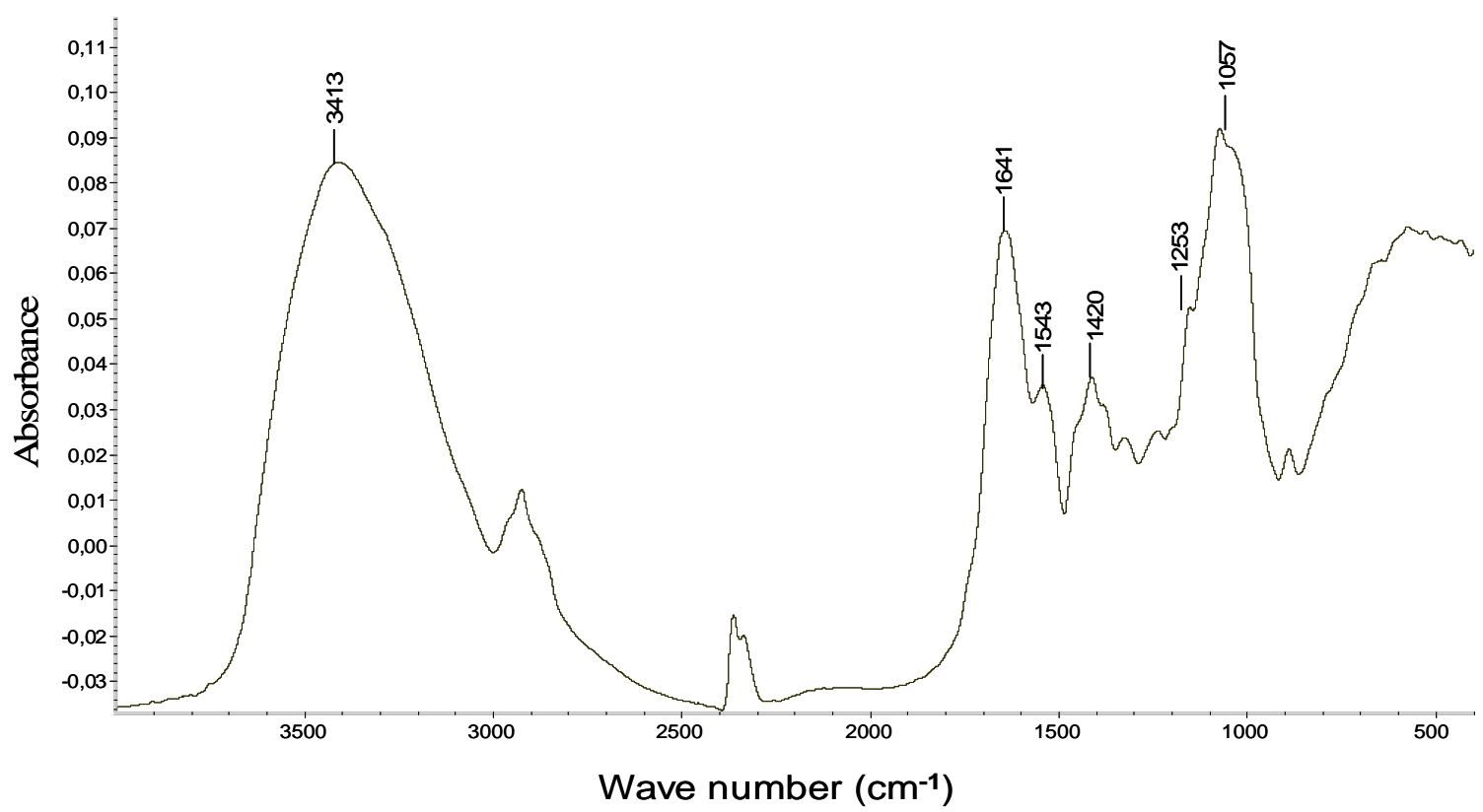

668

Fig. 3 Fourier transform-infrared spectroscopy spectrum of EPS-1 produced by the strain MC3B-10.

669

670

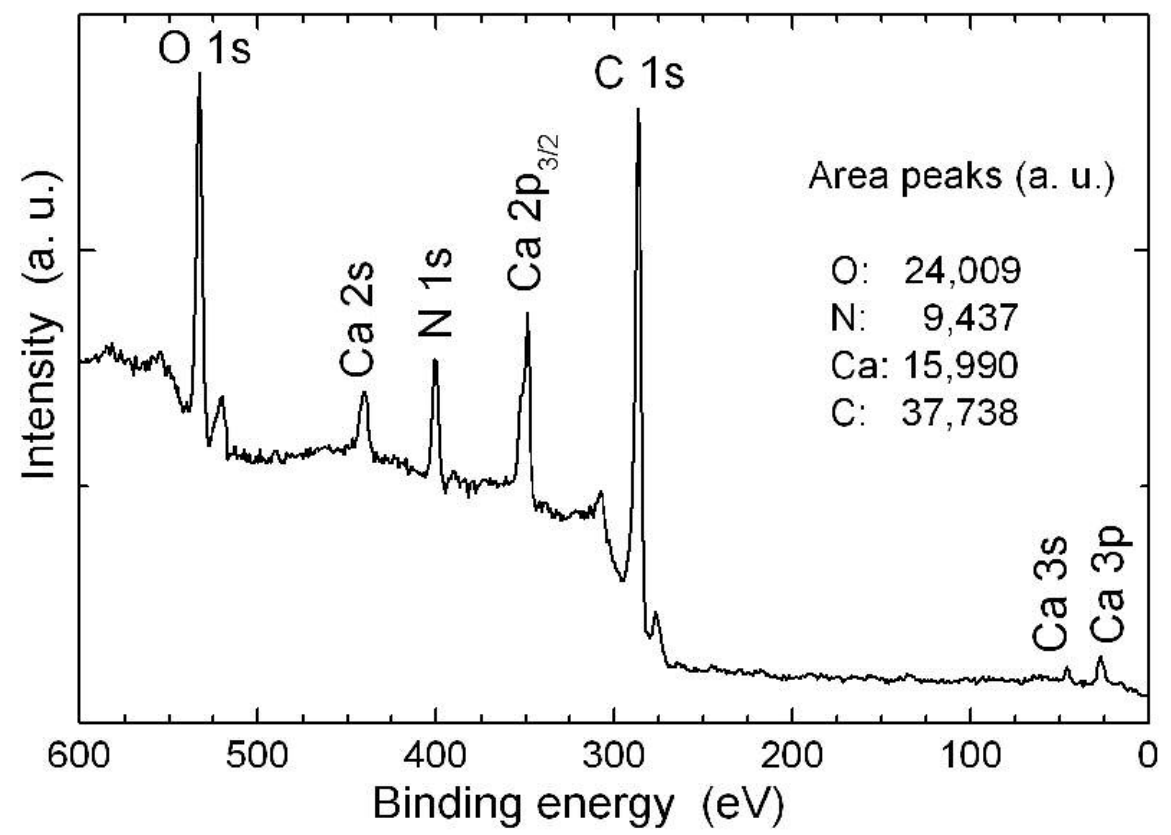

Fig. 4 XPS spectrum of the polymer produced by intertidal isolate MC3B-10. 


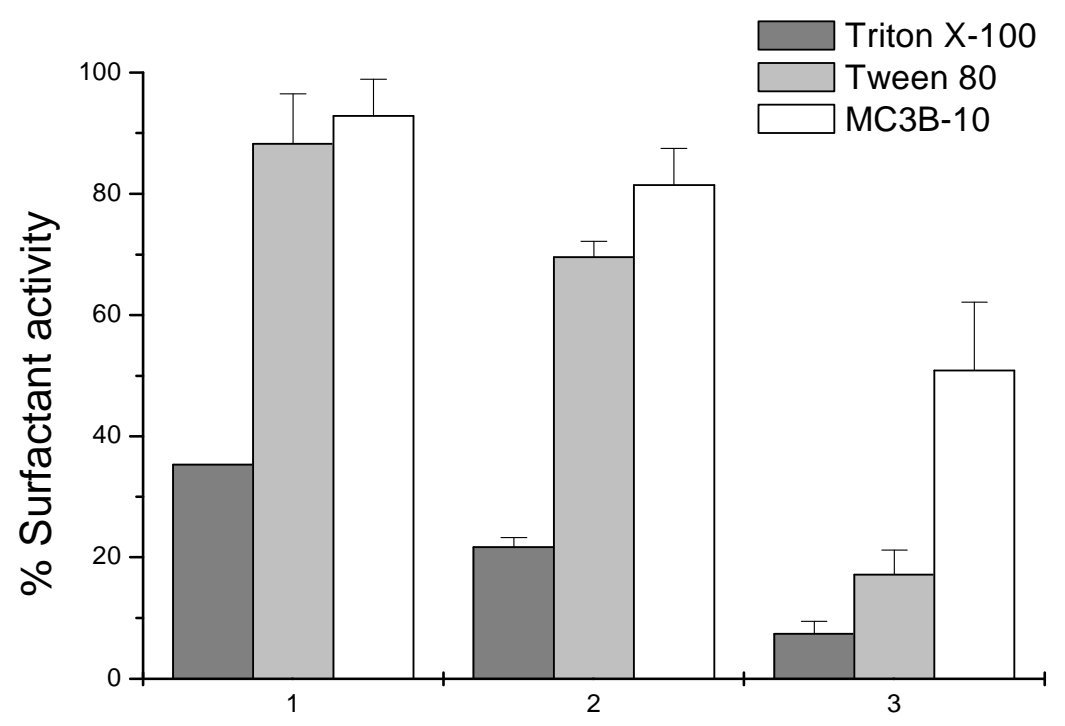

686

Hydrocarbons: 1) $n$-hexane; 2) n-octane; 3) n-hexadecane.

687

Fig. 5 Surfactant activity (emulsifying) of polymer MC3B-10 and commercial surfactants. Values are means of 688 triplicate determinations \pm S.D.

689

690

691

692

693 